\title{
Soldiers as farmers: army agriculture and food security in contemporary Nigeria
}

\author{
Nina G. Gavrilova* \\ Institute for African Studies of the Russian Academy of Sciences, 123001 Moscow, Russia
}

\begin{abstract}
FAO estimates that most of Nigeria's population is underserved; besides hunger, people experience effects of poor nutrition - diabetes, obesity, anaemia, etc. Formerly Nigeria was an agricultural country, but now its local production does not satisfy its own food demand. Farming is inefficient due to many factors, including conflicts between farmers and pastoralists, rooted in the very method of livestock breeding: pastoralists roam Nigeria all year round, while raising animals on ranches is barely practiced; as the population grows rapidly, agricultural plots begin to occupy traditional migration routes, and passing cattle destroy crops. Farmers take revenge by killing or stealing cattle. Consequently, Nigerians suffer from loss of livestock and crops and forced displacement. The government and the army established the Nigerian Army Farms and Ranches Limited (NAFARL), which enabled small-scale agricultural enterprises to organize on army lands. Thereby the army demonstrates advantages of non-nomadic livestock breeding and creates jobs. It is too early to draw conclusions on the effectiveness of NAFARL, as less than two years have passed since its inception. However, it may be argued that the army is capable of not only resolving conflicts, but also supporting the development of agriculture and achieving food security.
\end{abstract}

\section{Introduction}

The purpose of the study is to analyze the main reasons for the escalation of the hostilities between African pastoralists and farmers and assess its ramifications for agriculture and food security. The paper discusses some of the measures taken by the Nigerian Armed Forces to prevent the spread of conflicts. By organizing fenced ranches and demonstrating to the conflicting parties the effectiveness of this method of animal husbandry, the army aims at relieving tensions between herders and farmers.

For decades, the conflict between pastoralists and farmers has been developing in a number of African countries, resulting in loss of life and valuable property and the destruction of agricultural land. These tensions between the two important agricultural producers pose a serious socio-economic threat to the populations of the affected countries, primarily in terms of food security, since neither farmers nor pastoralists are able to fully engage in their principal production activities.

Since pastoralists own about $90 \%$ of the national herds in Africa and they are practically the only group of livestock producers in the countries of the continent, the nations exposed to the conflict face the pressing problem of providing their populations with foods rich in animal proteins.

The issue of conflicts between the two important socioeconomic groups of population is all the more relevant today. The consequences of clashes between nomadic cattle breeders and settled farmers have affected such countries of the African continent as the Central African Republic, Chad, Mali, Kenya, Somalia, Sudan, the Democratic Republic of the Congo, Burkina Faso, Ghana, Nigeria, etc.

Over the centuries, at certain times of the year, pastoralists drove cattle from north to south and back along established routes; state boundaries were not an obstacle to them.

At the beginning of the $20^{\text {th }}$ century, migration routes began to shift primarily due to climate change (increasingly frequent droughts and accelerating desertification) and population growth (loss of northern pastures due to the expansion of urban areas and agricultural land).

As a result of the migrations of shepherds and their herds, competition for land and water resources intensifies, which often leads to violent clashes and conflicts, the scale and intensity of which have increased significantly in recent years. The clashes are becoming increasingly violent, entailing mass killings, the destruction of villages, infrastructure and property, and large-scale waves of refugees.

The confrontation between these important agricultural producers leads to the destruction of crops and livestock, forced displacement of people and abandonment of material assets. The population engaged in agriculture does not feel safe and cannot fully engage in production processes.

Nigeria is the largest country in Africa by population (and the seventh in the world). Until the 1960s, Nigeria was renowned for the strength of its agricultural sector 
and almost entirely provided its residents with food. After independence, government support shifted from agriculture to the extraction of petroleum products, hence agricultural production fell into decay, and food security declined [1]. The agricultural industry ceased to ensure the country's food security.

The inefficient state of agricultural production is influenced by many factors: urbanization of the population, deficit of labour, low qualification and educational level of current agricultural personnel, etc. [2].

Nigeria's numerous security problems - kidnappings, armed robberies, cyber crimes, the activities of the Boko Haram terrorist group of radical Islamists [3] clashes between farmers and nomadic pastoralists [4] - further exacerbate the situation. The present paper will look into how the army attempts to resolve conflicts between farmers and pastoralists. In addition to resolving conflicts, the military takes part in training the population in innovative approaches in the field of agriculture and creates jobs for both people working in army structures and civilians.

\section{The impact of the conflict between shepherds and pastoralists on food security}

Nigeria has been experiencing food shortages for several decades. Among the factors affecting food security, the tensions between farmers and nomadic pastoralists deserve special attention. According to estimates by the International Crisis Group, in 2016 about 2500 people were injured as a result of these clashes [5]; in the first half of 2017 - 1300 [6].

In 2016, incidents involving pastoralists and farmers accounted for $44 \%$ of all deaths observed in the country. Experts consider these clashes as dangerous and bloody as the activities of Boko Haram in the northeast of the country, which in 2014 became the deadliest terrorist organization in the world [7].

A recent study of economic losses from the conflict between pastoralists and farmers in just four Nigerian states (Benue, Kaduna, Nassarawa and Plateau) showed that the federal government lost revenue of \$13.7 billion over the years of conflict, i.e. about half of all revenues of these states [8].

It was possible to calculate the number of people forcibly displaced due to the conflict; between 2015 and 2017 , it amounted to 62,000 people. Most of them seek refuge in other poor rural communities, which puts additional burden on their already strained resources [5]. In just one year, about 65,000 cattle were stolen and about 2,500 were killed because of the conflict [9].

The ensuing lost crop areas, trampled harvest, damaged irrigation facilities, lost labour and transportation resources could not be estimated. The conflict between pastoralists and farmers deprives the population of homes, work, food, and makes them vulnerable to food shortages.

\section{The present state of food security}

According to the Food and Agriculture Organization of the United Nations (FAO), food security should be analyzed in the following four dimensions: access to food, food availability, stability of the food supply and the quality of nutrition. In Nigeria in 2016-2018, about 26 million people were undernourished, 12 million people were acutely lacking food, every 10th child under 5 years old was malnourished, and every fifth child was stunted (fig. 1).

Malnourished children suffer from irreparable mental retardation and physical growth retardation; they become unable to study and drop out of the education system, remaining at best in the role of unskilled workers for their whole lives. The adult population of the country that suffers from malnutrition also cannot be considered full-fledged workers [10].

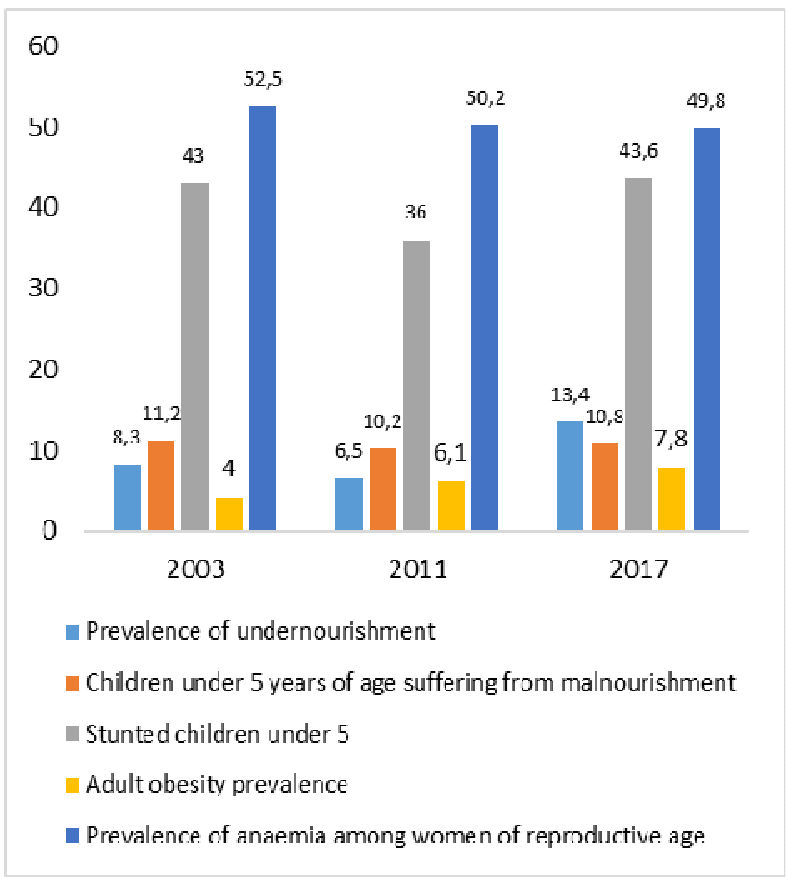

Fig. 1. Certain indicators of food security in Nigeria, according to FAO [11]

It should be noted that Nigeria is significantly below the global average in terms of food availability and the quality of nutrition. For instance, food production per person in Nigeria is $30 \%$ below the average, protein supply $-30 \%$ below, and animal protein supply is only $1 / 3$ of the world average. The share of consumed root crops, cereals, and tuber crops is $32 \%$ higher than the world average (table 1).

The average value of protein intake per day ( $9 \mathrm{~g})$, compared with the recommended norm of $65 \mathrm{~g}$, is extremely inadequate and entails consequences in the form of stunted children and adult weight loss [11]. A high intake of carbohydrate foods, such as legumes and root crops, indicates an unbalanced diet and inadequate intake of essential nutrients in rural areas.

Improper diet causes health problems in a large part of the population of Nigeria, especially in children. For example, vitamin A deficiency in children reduces their 
ability to resist infections and annually leads to the death of more than half a million African children [11]. An unbalanced diet combined with a poor sanitary environment has increased the vulnerability of rural residents to numerous diseases, such as malaria, tuberculosis, and whooping cough. Each year, the media reports on the beginning in Africa of an epidemic of a disease that has not manifested itself in developed countries for a long time.

Table 1. Comparison of food availability and nutritional balance in Nigeria with the world, Africa and West Africa, \% (average for 2000-2018), according to FAO [11]

\begin{tabular}{|l|l|l|l|}
\hline Indicators & World & Africa & $\begin{array}{c}\text { West } \\
\text { Africa }\end{array}$ \\
\hline Per capita food production, \$ & 69.8 & 117.4 & 104.3 \\
\hline $\begin{array}{l}\text { The share of the energy value of } \\
\text { nutrition derived from cereals, } \\
\text { root crops and tubers, \% }\end{array}$ & 132.0 & 95.7 & 97.1 \\
\hline $\begin{array}{l}\text { Average protein supply } \\
\text { (g/capita/day) }\end{array}$ & 70.3 & 139.1 & 114.3 \\
\hline $\begin{array}{l}\text { Average supply of protein of } \\
\text { animal origin (g/capita/day) }\end{array}$ & 33.3 & 75.0 & 90.0 \\
\hline
\end{tabular}

Thus, due to the aforementioned reasons, including the escalating conflict between pastoralists and farmers, the agricultural industry has ceased to satisfy the population's demand for food products to a sufficient extent, and the country's food security has been significantly undermined. Because of conflicts between farmers and pastoralists, many farm animals perish or their productivity decreases, which negatively affects the volume of production, causes an imbalance in the diet of the country's population and has an adverse impact on the health of the nation.

\section{NAFARL: to settle conflicts and increase food security}

Nigerian Army Chief of Staff Tukur Buratai took the initiative to create a special army structure that would not only carry out operations to maintain security, restore order and rebuild key infrastructure in conflictaffected areas, but would also take part in the agricultural production process in order to increase the welfare of military personnel and their families and facilitate the stabilization of food security. With the support of the Government of Nigeria, in July 2018, a decision was made to establish Nigerian Army Farms and Ranches Limited (NAFARL) [13].

One of the most important tasks of NAFARL is resolving conflicts between farmers and pastoralists. These nomads, in search of food and water for animals, roam the country for almost the entire year, moving herds from place to place; keeping animals on a farm in Nigeria is almost never practiced. For centuries, nomadic routes were permanent, pastoralists and farmers did not trouble each other, so there was no reason for conflict [14]. But due to the sharp increase in the population, the need arose to increase food production and, accordingly, to expand the area for its cultivation. As a result, farms had to be built on livestock migration routes. Passing livestock trample crops, depriving farmers of the harvest; farmers take out their wrath by killing or hijacking cattle.

This vicious circle leads to material losses of producers of both crop and livestock production; minor conflicts develop into armed clashes and spread throughout the country, frightening civilians and worsening the economic and socio-political situation [15]. Such instability factors not only affect production and food security, but also directly worsen Nigeria's investment climate, deterring potential investors and thereby narrowing financial flows to various sectors of the economy, including the agricultural sector.

Military units at their deployment sites are called upon to use an alternative method of raising livestock that will not cause conflicts - the establishment of livestock ranches throughout the country. When keeping animals at a ranch, the need to overcome long distances in search of food and water disappears, since the farm will have its own pasture; cattle will be kept in a limited, fenced area, which will exclude the possibility of damage to neighbouring farms.

The obligatory veterinary service of animals is planned for. NAFARL intends to process milk, meat and meat products right on the ranch. In the future, the products will be sold to the local population or used to feed the army.

It is assumed that the army will be engaged in animal husbandry and crop production at an approximate ratio of 50:50, while taking into account the specialization of each region: where rice grows well, rice fields will be created; where natural conditions make it possible to engage in animal husbandry, it will be paid special attention. It is assumed that non-food crop plant remainders will go to livestock feed, that is, non-waste production will begin to develop, and the crop and livestock industries will be connected with each other. Barracks participating in the NAFARL project will specialize in one or several types of animal husbandry and farming, such as livestock raising, fishing, poultry farming, greenhouse farming and plantation maintenance [13].

The army owns lands, which over time will become ranches throughout the country. Thus, the armed forces plan not only to serve as peacekeepers between the pastoralists and the farmers, but also to capitalize on their domestic income from farming. During the implementation of the NAFARL project, employment opportunities will expand not only for people related to the army (members of military families), but also for civilians. At the same time, the military and their families are guaranteed lifetime employment in agriculture with the support of NAFARL.

The development of the Ranch and Farms of the Nigerian Army project suggests that over time, small agricultural organizations within the barracks will turn into large agricultural centres whose activities will be based on the use of modern effective technologies. It is planned to build a pilot standardized integrated farm, on which cattle, poultry, fish and crops will be raised. NAFARL will contribute to the further formation of the country's agricultural economy by supporting the government's agricultural and food programs. 
It is too early to summarize the results of NAFARL; the project was launched less than two years ago. However, the first project in January 2018 was the Giri ranch (the Federal Capital Territory - Abuja), and in April 2019 the opening of a ranch in Kontagora followed. The army acquired 436 thousand hectares of land in the state of Nassarawa to set up agricultural facilities; work began on organizing a ranch in Jaji (Kaduna). The total number of herds kept on these ranches is still small and amounts to 3 thousand cows, 1 thousand goats and 1 thousand sheep; the livestock is made up of local, climate-resistant breeds. Civilian workers were involved in arranging and maintaining the ranch [13].

The NAFARL project secured the support of the Ministry of Agriculture and Rural Development, and Minister Audu Ogbeh acknowledged that raising cattle in a closed area (ranch) was the only solution to the problem of tensions between pastoralists and farmers and that the Nigerian army was "showing the world that soldiers don't only wage war but also promote permanent peace." [16] The Ministry has repeatedly helped with the opening of army ranches: mixed feeds for animals and machines for their production were delivered to the military. The Ministry took control of the issues of scientific study and organization of the process of livestock breeding in closed territories, as well as the creation of milk and meat processing plants.

\section{Conclusion}

Governments of countries affected by conflicts between farmers and pastoralists are paying increased attention to developing and improving policies to mitigate the tensions. At the moment, most measures are restrictive in nature: for example, bans on livestock grazing, restrictions on grazing areas, the eviction of foreign pastoralists from the country, which further aggravate the conflict situation.

However, there are peaceful solutions. Two scenarios are proposed: either the creation of a ranch to limit the movement of herds, or the construction of corridors for cattle migration. The deterioration of food security due to conflicts between farmers and pastoralists threatens to become a fundamental challenge to the socio-political stability of Nigeria [5].

Therefore, the development of agricultural production by the army and the establishment of fenced ranches will help smooth out these conflicts and their consequences, lay the foundations for future economic growth and political stability, including by providing jobs for the military and members of their families, as well as to everyone interested in agricultural activities. The organization of ranches and farms by the armed forces will help develop long-term strategies for economic and political development.

By contributing to the creation of new jobs, the army helps to achieve food security for the most vulnerable segments of the population, including members of the military families who have lost breadwinners, who died or were injured in resolving conflict situations.
The presence of army units in agricultural areas, including in areas affected by conflicts between pastoralists and farmers, will restore order and strengthen the confidence of the general public in the ability of the government to respond to security threats.

The Nigerian army, realizing the importance of achieving lasting peace and stabilizing the economic situation, seeks to ensure the safety of the population and create an environment in which local communities can engage in their activities without fear of conflicts and their consequences.

\section{References}

1. Agriculture, in Nigeria, A Reference Monograph (Instit. for Afric. Studies, Moscow, 2013)

2. N.G. Gavrilova, Eurasian Law J., 5(120), 380-384 (2018)

3. T.S. Denisova, Asia and Africa today, 8, 12-17 (2015)

4. S.V. Kostelyanets, Vostok, 4, 196-202 (2014)

5. International Crisis Group, Report no. 252/Africa. Herders against Farmers: Nigeria's Expanding Deadly Conflict (2017), Retrieved from: https://www.crisisgroup.org/africa/westafrica/nigeria/252-herders-against-farmers-nigeriasexpanding-deadly-conflict

6. International Crisis Group, Report no. 262/Africa. Stopping Nigeria's Spiralling Farmer-Herder Violence (2018), Retrieved from: https://d2071 andvip0wj.cloudfront.net/262stopping-nigerias-spiralling-farmer-herderviolence.pdf

7. S.V. Kostelyanets, Paths to Peace and Security, 2, 101-113 (2016)

8. Mercy Corps, The Economic Costs of Conflict: Evidence on Violence, Livelihoods and Resilience in Nigeria's Middle Belt (July 2015), Retrieved from: https://www.mercycorps.org/researchresources/economic-costs-conflict-nigeria

9. S.C. Ogala, Advan. in Multidisciplinary \& Sci. Res. J. Publ., 4, 101-112 (2018)

10. N.G Gavrilova, T.S. Denisova, Asia and Africa today, 7, 54-58 (2019)

11. FAOSTAT. Suite of Food Security Indicators. Retrieved from: http://www.fao.org/faostat/en/\#data/FS

12. O.O. Ikelegbe, D.A. Edokpa, Afric. J. of food, agricult., nutrit. and develop., 13(5), 8388-8400 (2013)

13. The Nigerian Army Farms and Ranches Ltd (NAFARL), Retrieved from: https://nafarl.com.ng/about/

14. S.V. Kostelyanets, Asia and Africa today, 1, 40-43 (2010)

15. T.S. Denisova, J. of the Instit. for Afric. Studies, 4, 40-58 (2017)

16. The Sun Nigeria, Buratai showcases Army's ranch in Abuja (17.01.2018), Retrieved from: https://www.sunnewsonline.com/burataishowcases-armys-ranch-in-abuja/ 